\title{
Restructuring of Peri-Urbanization around Railway Stations in Some French Urban Areas
}

\author{
By Anissa Benaiche*
}

The continuation of peri-urbanization in France (particularly in metropolitan urban areas) is at the origin of some urban dysfunctions. This situation leads us to reflect on the spatial structuring of peri-urbanization in relation to sustainable development. Current reflection focuses on the coherence urban planning/ transportation, which allows slowing down the urban dispersion phenomenon by encouraging urban concentration around railway stations. Consequently, the aim of this paper is to verify the tangible aspect of this reflection upon the three metropolitan urban areas of Pays de la Loire region (West France): Nantes, Angers and Le Mans. In order to know if railway stations could become dense clusters, the methodology is concentrated on the morphological study of communes served by a railway station. The principle tool used is the reading of some urban planning documents: Local Urban Development Plan and Land use plan. This study leads initially to detect realities and local practices with regard to the coherence urban planning/transportation. It reveals secondly that railway stations, in peri-urban space, don't offer the same potentialities and strategies of development. Indeed, there is a plurality of strategic profiles: communes without strategies and without projects, communes with a strategy for housing, communes with a strategy for employment, communes with a project articulating urban development and displacements.

\section{Introduction}

Urban areas are increasingly confronted with a double pressure manifested by metropolization and peri-urbanization. ${ }^{1}$ Metropolization characterizes the occupation of space by concentrating human and material wealth ${ }^{2}$ towards cities, areas or urban regions. ${ }^{3}$ The peri-urbanization tends to respond to the demographic growth of the city, in its morphological extension beyond its central part. ${ }^{4}$

In France, the new zoning in urban areas 2010 carried out by INSEE (National Institute of statistics and economic studies) demonstrates the

\footnotetext{
* Researcher, Nantes University, France.

1. A. Da Cunha, P. Knoepfel, J.-P. Leresche and S. Nahrath, Enjeux du développement urbain durable: transformations urbaines, gestion des ressources et gouvernance (PPUR presses polytechniques, 2005); F. Sager, "Institutions métropolitaines et coordination des politiques publiques: une aqqc des arrangements politico-administratifs d'articulation entre urbanisme et transports en Europe," Revue internationale de politique comparée 11, no.1 (2004): 67-84.

2. F. Ascher, Dynamiques métropolitaines et enjeux sociopolitiques (1995) http://bit.ly/ 2D0UMAg; F. Ascher, L'âge des métapoles, préface d'Alain Bourdin. La Tour d'Aigues (Editions de l'Aube, 2009).

3. J. Grebert, F. Toupin and J. M. Beauvais, Les petites gares du périurbain en région tourangelle: continuité territoriale et rupture de charge (Atelier d'urbanisme de Tours, Paris: PREDIT, 1999).
}

4. G. Wackermann and J. Dubois-Maury, Ville et environnement (Ellipses, 2005). 
continuation of the peri-urbanization at the national level. ${ }^{5}$ Several factors can be observed in terms of urban planning, such as the economic attractiveness of city centers, the loosening of residences and jobs, the urban development of peripheral sectors which are unsuitable for alternative modes of transport, low density and functional segregation. Other factors can be observed in terms of mobility such as the strong growth in car use, the lengthening of distances traveled contributing to the congestion of the road network and the increase in nuisances ${ }^{6}$. In order to overcome these trends, current research is increasingly focusing on the coherence urban planning/transportation, which makes it possible to curb the phenomenon of urban dispersion by encouraging urbanization around railway stations. ${ }^{7}$

Railway stations represent the first element of the perception of supply and quality of transport by users. ${ }^{8}$ Their issue is measured by their ability to cope with automobile competition ${ }^{9}$ by modifying the relationships of complementarities between different modes of transport. ${ }^{10}$ The stations also constitute a heritage and a laboratory of contemporary urban production, ${ }^{11}$ that's why some researchers measure the potentials of densification around stations. ${ }^{12}$ They represent a strategic space indispensable for the functioning of modern metropolises and a striking feature of a new urban landscape. ${ }^{13}$ Consequently, the main objective of this paper is to determine whether periurban stations could become dense clusters.

The methodology used focuses on the morphological and regulatory study of the peri-urban communes served by a railway station, by identifying local practices with regard to the coherence urban planning/transportation and the realities of development in relation to rail transport. The main tool used is the documentary reading of Local Urban Development Plans (PLU, $)^{14}$ land use plans (POS) and the charter of development, even though it is not strategic.

5. Aura, La ville, toujours plus loin? (Portraits du périurbain angevin) (AURA editeur, 2012).

6. Certu, Effet de serre, organisation urbaine, politiques de déplacements (Journée d'étude, Octobre 2003).

7. M. Homocianu, Modélisation de l'interaction transport-urbanisme-Choix résidentiels des ménages dans l'aire urbaine de Lyon, Doctoral thesis (Université Lyon 2, 2009).

8. G. Bonnet, A. Canet, L. Houles and B. Thomé, La régionalisation des transports ferroviaires. Enseignement de l'expérimentation et perspectives (Lyon: CERTU, 2001).

9. N. Baron and N. Roseau, "Les gares au miroir de l'urbain," Flux 2016/1, no.103-104 (2016): 1-8.

10. V. Stránský, "Des quartiers de gare favorables aux modes actifs pour une mobilité régionale énergétiquement sobre. Point de vue d'acteur," Flux 2017/1, no.107 (2017): 74-90.

11. Baron and Roseau, "Les gares au miroir de l'urbain," (2016): 1-8.

12. A. Brès, "Train stations in areas of low density and scattered urbanisation: towards a specific form of rail oriented development," Town Planning Review 85, Issue 2 (2014): 261 272. DOI:10.3828/tpr.2014.16; T. Leysens, Reconfiguration des réseaux de transport et renouveau urbain: l'enjeu d'un urbanisme orienté vers le rail, Doctoral Thesis (Université Lille 1, 2011).

13. A. Levy, "La renaissance des gares," Médium 2008/2, no.15 (2008): 39-47. DOI 10. 3917/mediu.015.0039.

14. The PLU is a regulatory and operational urban planning document allowing the coherence urban planning/transportation. It replaced the land use plan and introduced major new developments such as the spatial planning and sustainable development proposal. The 
Three metropolitan urban areas of Pays de la Loire region (western France): Le Mans, Angers and Nantes are selected for the study. They cover respectively territories of 124, 133, 114 communes (situation of 2009), spread over a total area of 2,015,2,354,3,302 $\mathrm{km}^{2}$ and gather $338,981,394,710$, 862,111 inhabitants (i.e. densities of 168, 167 and $261 \mathrm{Hab} / \mathrm{km}^{2}$.) These three sites are interesting both for the progression of peri-urban spaces on the scale of urban areas and the presence of important railway networks serving these spaces (Figure 1.) Railway stations of these sites have a preponderant role in the regional railway policy, which is divided into several actions: accessibility of the regional network, rehabilitation of buildings closed to passengers, development of interchange stations and encouragement of the "train-bike" system. The following sections detail the results of the study on each site.

\section{A Positive Assessment in Le Mans}

Most of the peri-urban communes served by railway stations are covered by a PLU approved on October $1^{\text {st }} 2013$. The content of the different PLU that we have examined shows that the railway stations in the peri-urban area do not offer the same potential and strategies of urban development. That being said, we have several profiles.

\section{Communes without Development Strategy or Planning Documents}

This category concerns the two communes of Teillé and Domfront-enChampagne. Teillé is currently not covered by an urban planning document (PLU, POS or communal map), which makes it difficult for us to know the potentials of densification around the railway station.

The commune of Domfront-en-Champagne is covered by a POS revised in 2001. It does not incorporate the stakes of the coherence urban planning/ transportation. The station of Domfront-en-Champagne is located in a site surrounded on both sides by zones NB (according to the regulations of the POS); they are natural areas which are not protected. Diffuse constructions, partially served by equipments, are implanted in these areas and it is not intended to supplement them. Consequently, there is no potential for densification around the railway station since the areas planned for the urban extension are far from the railway.

PLU has the possibility of fixing a minimum density of construction in sectors located near the existing or planned public transport (article L 123-1-5, $13^{\circ}$ bis of urban development code). It also has the possibility of fixing a maximum number of parking areas to be realized during the construction of buildings (for use other than the dwelling). 


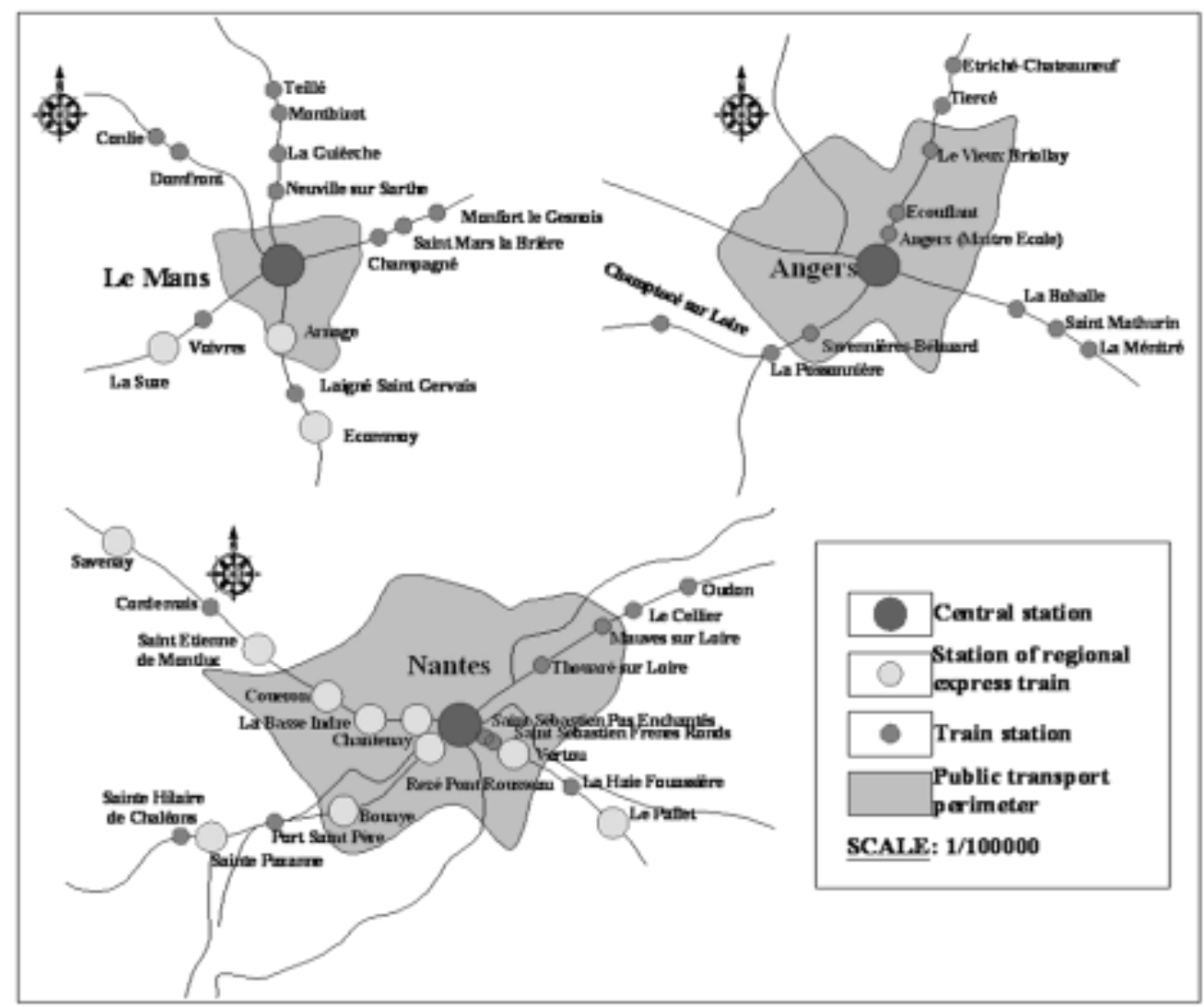

Figure 1. The Three Railways

Source: Accessibility Plan of the Regional Transport Network of Pays de la Loire region, June 2008.

Demographic Renewal and Principle of Densification

Sustaining equipments and services and combating the aging of the population generally involve a process of demographic renewal, with a controlled pace of new inhabitants and a supply of adapted housing. This offer of housing becomes interesting if we opt for an urban form economical in space by encouraging densification. The five examples of Montbizot, Ecommoy, Conlie, Neuville-sur-Sarthe and Champagné show the way in which the supply of housing and the compactness of the peri-urban space tend to be consolidated.

For the commune of Montbizot, only the city center will be able to accommodate new populations and economic activities. Intensification is possible around the railway station (Figure 2) with the presence of two areas with immediate urbanization (AU1) and a zone to be urbanized immediately for economic activities (AUZ1.) ${ }^{15}$ The densification of the large village will be accompanied by a pattern of pedestrian and automobile connections in order to promote a pedestrian practice and avoid unnecessary automobile

15. The station is also surrounded by the zone UZ (urban area of economic activities) and zone AUZ2 (zone to be urbanized for economic activities and opened later). 
movements. The commune could immediately urbanize the economic zone around the station.

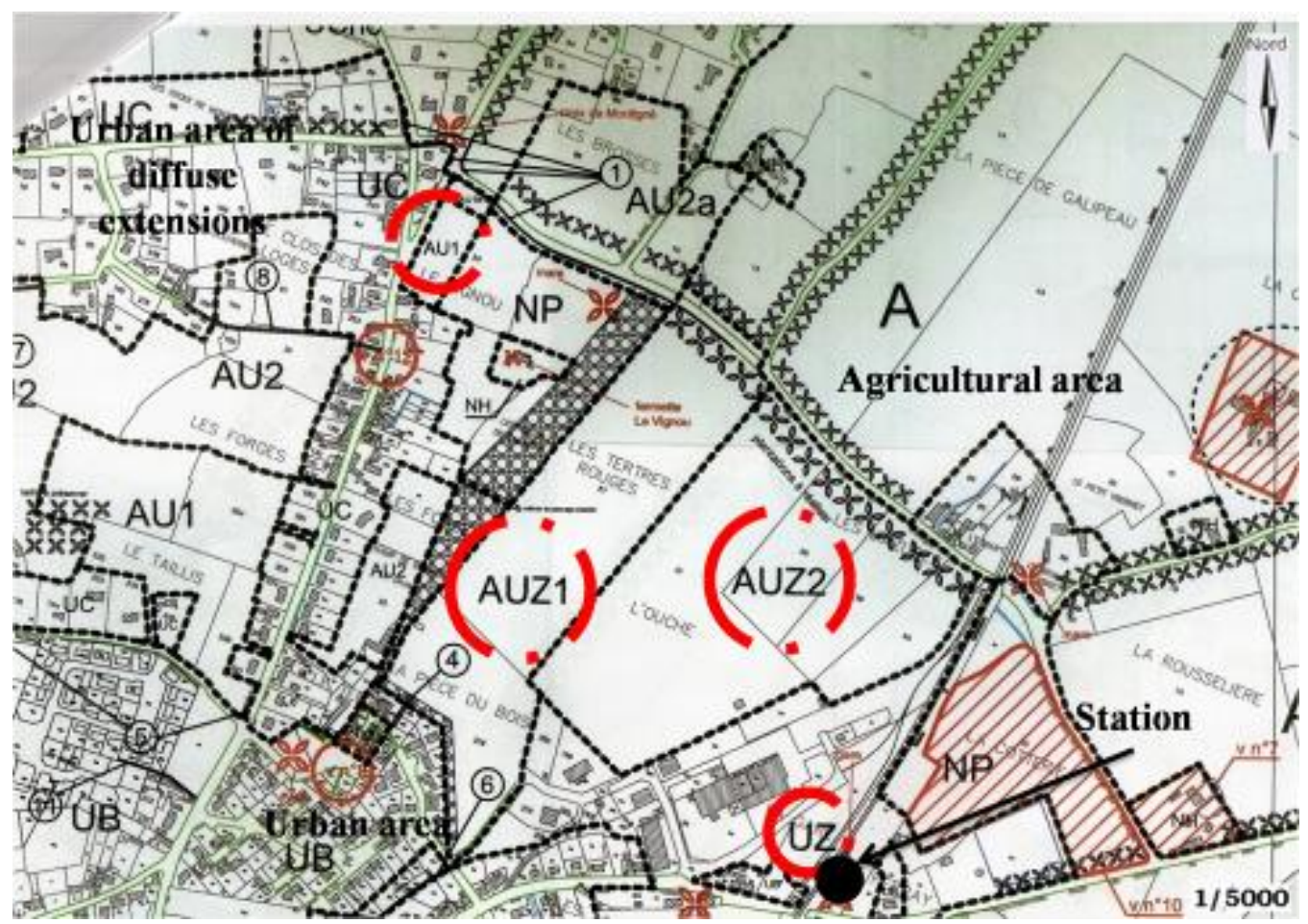

Figure 2. Densification around the Station of Montbizot

Source: PLU of Montbizot.

In Ecommoy, the railway station is located in the heart of the village where $80 \%$ of the population is concentrated (the other part is dispersed on the municipal territory). This station is therefore located between two regulatory zones of the PLU: Uc and Up. The first represents the areas allocated to the agglomerated central habitat with various activities such as shops, services, etc. The second concerns the peripheral areas which have a vocation for individual houses. The possibility of densification is possible around the station since a parcel of $10,000 \mathrm{~m}^{2}$ has been put on sale recently by SNCF réseau (previously réseau ferré de France.) Several projects can be registered in the future especially since the land is classified as an urban area having vocation for housing (Up) served by collective sanitation. Functionally, the PLU insists on the principle of urban connection between the different sectors of the large village (Figure 3.) We predict for example to connect the neighborhood near the station with the city center and with a future urban development space located to the west of the city center.

As for the example of Conlie, the elected representatives opt for the urban renewal of the existing fabric and the filling of hollow teeth ${ }^{16}$ by means of a piecemeal urbanization. The commune also envisaged, in its PLU, zones to be urbanized for housing (AUh) which can be realized in the form of

16. The hollow teeth are unbuilt spaces surrounded by built plots located in the urban fabric. 
subdivisions (sale of building plots) or group of houses (sale of built land). Consequently, they may be managed by the commune itself, by the professional developer or by the owner of the land. In this context, the sector of station of 1.1 ha (Figure 4) is an area anticipated for housing; grouping parcels left free by the linear urbanization between the two streets of the station in the north and Sainte Sabine in the South. A possible coordination between urban planning and rail transport is therefore possible in the communal area of Conlie thanks to the densification in the vicinity of train and the possibility of promoting the use of bike because of the very pleasant communal setting. Another area known as UPa ( $0.3 \mathrm{ha})$ located in the southern sector of the station, is also interesting but it is not served by the collective sanitation network.

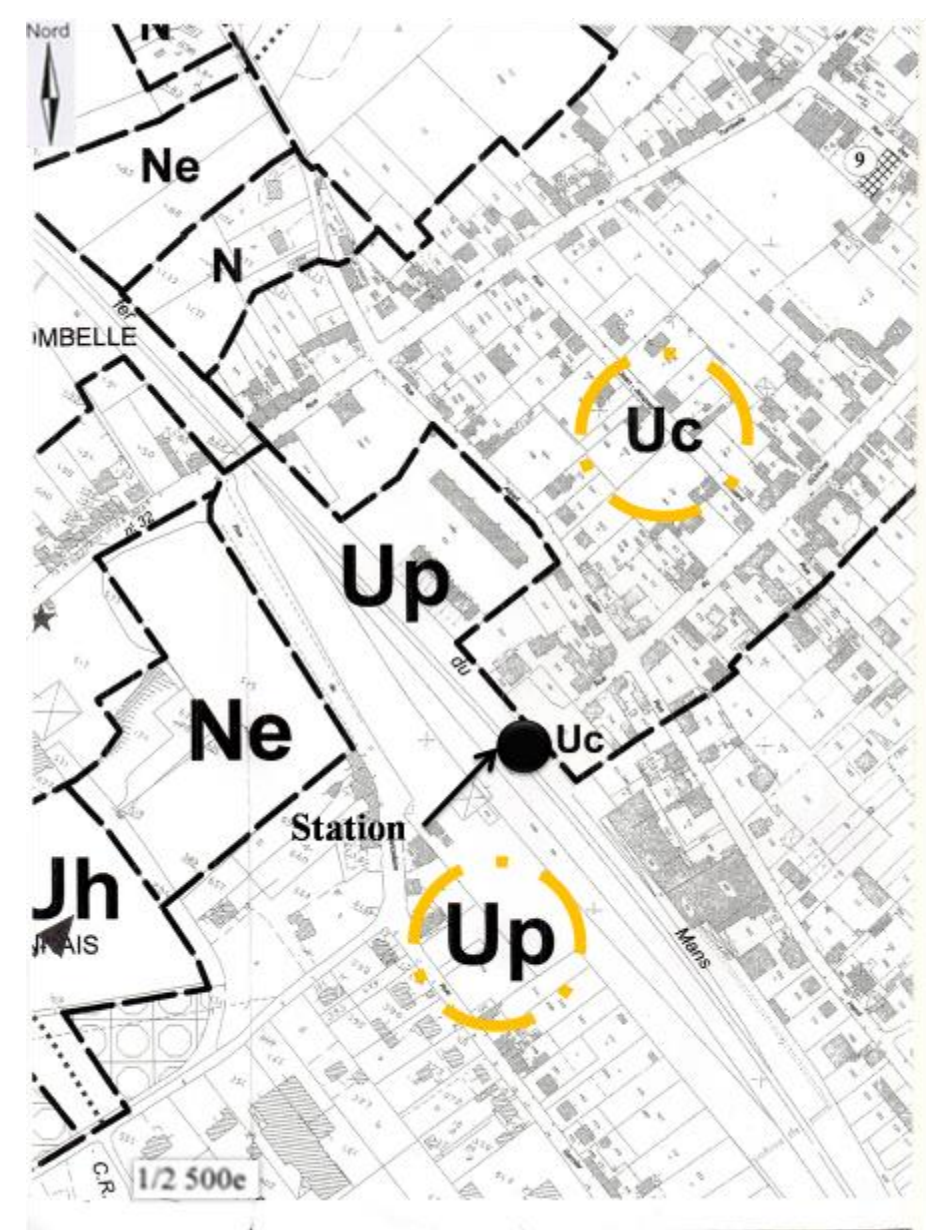

Figure 3. Localisation of the Station of Ecommoy Source: PLU of Ecommoy. 


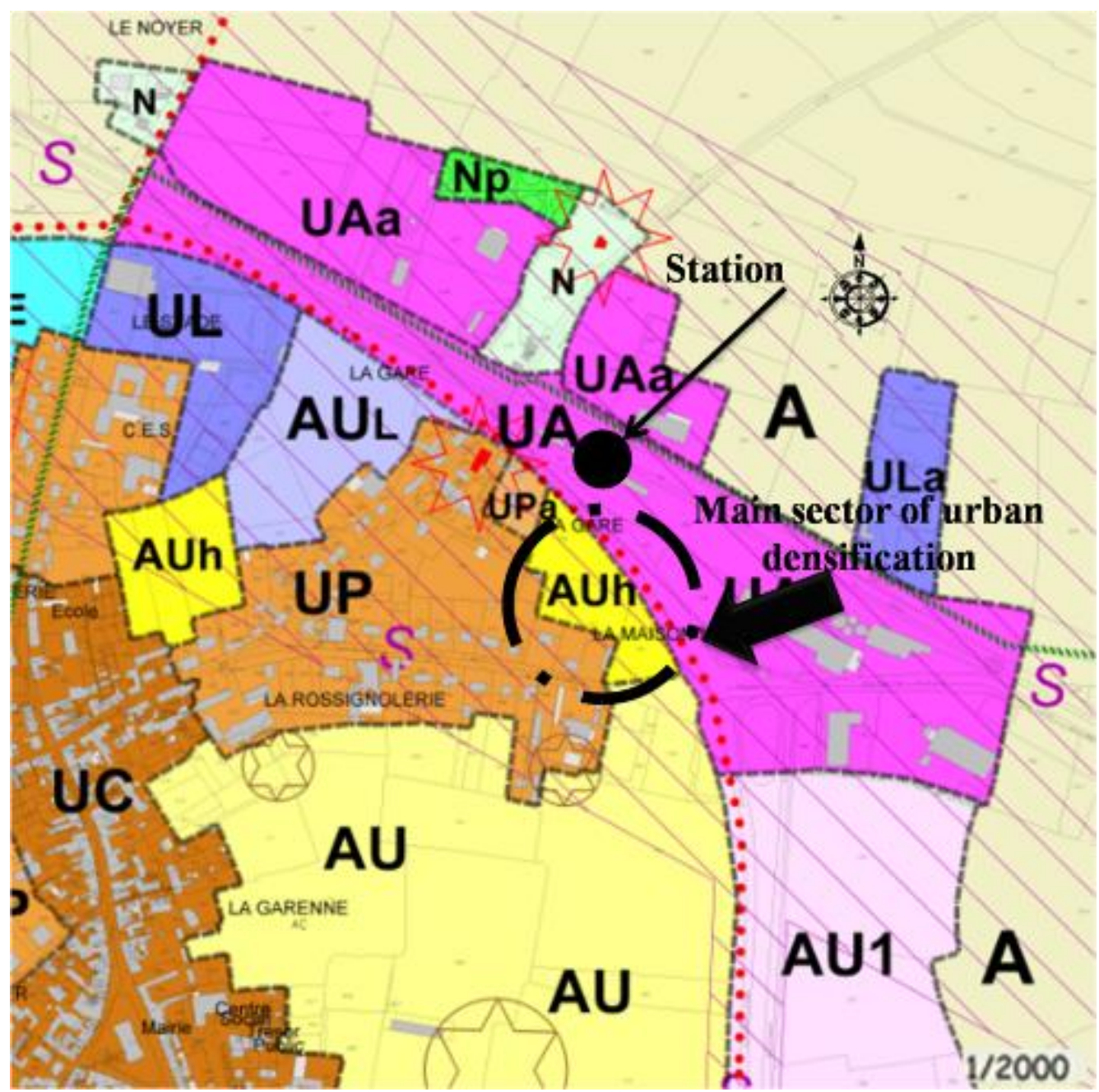

Figure 4. Densification around the Station of Conlie

Source: PLU of Conlie.

In Neuville-sur-Sarthe, the possibility of densification (housing and economic activities) around the railway station is possible by the presence of urbanization zones destined for economic activities (AUa) and housing (AUh). This densification would make it possible to round the village in a coherent way.

Finally, the commune of Champagné is an interesting example concerning the urban renewal. A central zone of collective housing (Up3) near the railway station is conducive to urban renewal (Figure 5) owing to the demolition of three towers in favor of small multi-unit buildings (i.e. 70 rental housing). This makes it possible to densify the large village, which concentrates $75 \%$ of the population. The commune could also solidify its economic attractiveness by developing the zone $\mathrm{Uz}$ which is destined to receive industrial, artisanal and commercial activities, while taking advantage of the proximity of Le Mans and the railway service. At the same time, the PLU predicts to improve the accessibility of the station and increase the parking capacity in the vicinity. 


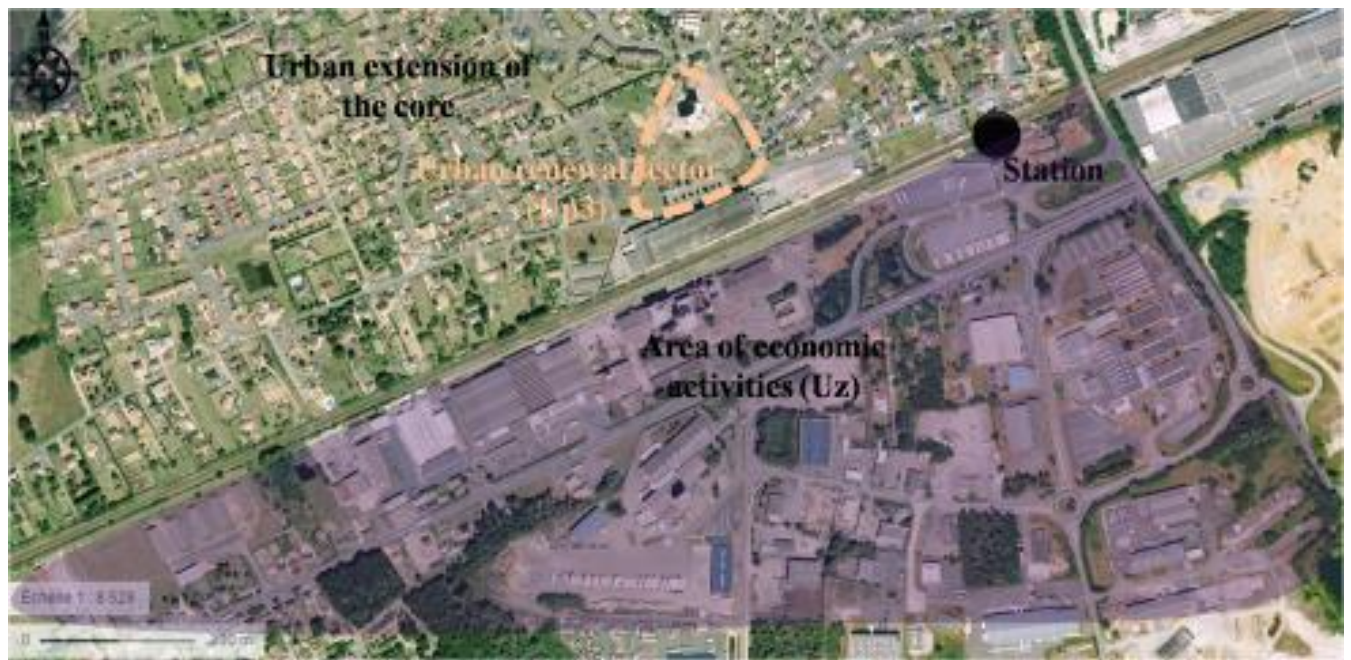

Figure 5. Densification and Urban Renewal around the Station of Champagné

Source: http://www.geoportail.gouv.fr.

\section{Employment Strategy}

For the commune of Montfort-le-Gesnois, the elected representatives want to implement a dynamic development strategy through employment. The community zone of activities located in the south of the commune and served by the railway station could be expanded and bring jobs over time. Some guidelines of the PLU are interesting in terms of coherence urban planning/transportation: development of a soft link in connection with the railway station, filling of hollow teeth, development of lands supply for activities and development of recreational areas. The filling of hollow teeth of the zone UP (peripheral urban area), where the station is located, will happen as opportunities or transfers of property.

An Ambitious Project around the Polarity of "Joué-L'Abbé, La Guièrche, Souillé"

The commune of La Guièrche aims a demographic growth close to 1,300 inhabitants by 2021. To do this, the elected representatives reflected on the location of this new population in the framework of sustainable urban development. The response of the communal PLU is positive since all zones to be urbanized (including AUh zones) are located within 500 meters as the crow flies from the station (located in the heart of the village, surrounded by the UB and UA zones). The UA zone is an urban area of old mixed-use housing which comprises the bulk of the communal residential economy and is in fact conducive to densification and rehabilitation. The UB zone is an area of individual housing integrating general operations in the form of subdivisions. In general, densification around the railway is possible but it runs up against problems of access to the plots. The most important thing is that the railway station is confirmed as a centrality and that the PLU seeks to facilitate soft mobility, especially pedestrian corridors, towards this centrality 
(Figure 6). At the intercommunal scale, it is planned to create a cycle path from the church of the commune of La Guièrche to the neighboring commune of Joué l'Abbé (following the regional road 149) with a possibility of extending in direction of the commune of Souillé. This soft connection makes it possible to redefine a new parking strategy for the railway station.

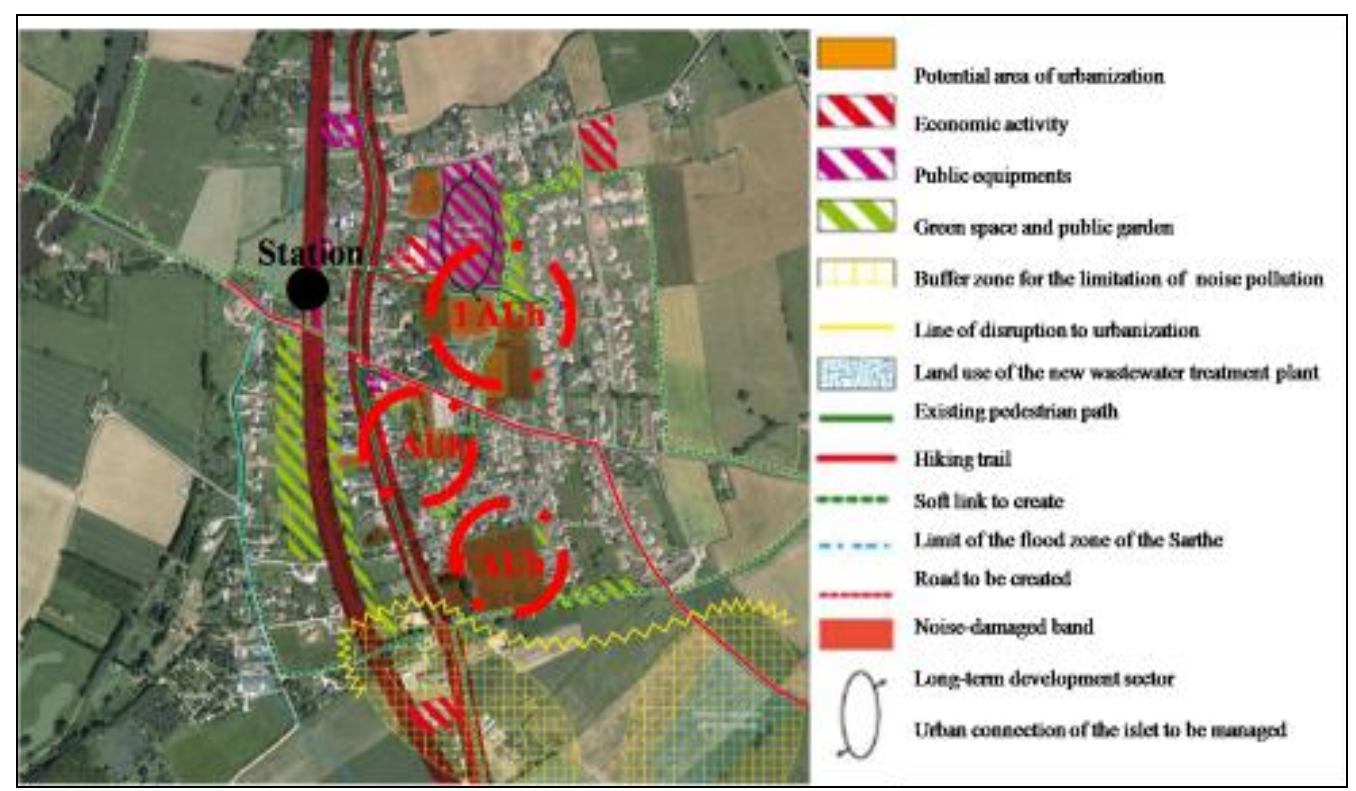

Figure 6. Coordination between Urban Planning and Displacements

Source: PLU of La Guièrche.

\section{Densification around Railway Stations in Angers, Mixed Results}

All communes served by the railway, separately from the commune of Saint-Mathurin-sur-Loire, are covered by PLU currently approved. Savennières, Briollay and Ecouflant are concerned by the project of a community PLU.

The consultation of the documents shows firstly that, at the local level, there is a logic of urban recomposition within the existing envelope (large villages) in the sense of protecting the environment and maintaining the rate of population growth; secondly, there is not much potential for densification around the railway of Angers due to the non-strategic location of some stations and the presence of natural and physical constraints. Here we try to argue our remarks with examples.

No Densification Potential around the Stations of Etriché, La Possonnière and Champtocé-sur-Loire

The railway stop of Etriché is a true station of fields which is located between two agglomerated zones: Etriché and Chateauneuf-sur-Sarthe. The station is accessible by a very busy departmental coach; it is located next to a zone of economic activities, in a natural space dotted with dispersed housing 
which offers remarkable visual perspectives. Despite the frequentation of this station, its location is not strategic and in our opinion it would be desirable either to move this station and insert it in a denser area or to promote soft mobility in the interior of fields; by creating pedestrian circuits or cycle paths to facilitate the accessibility of users. There is no potential for densification around the station since the PLU of the commune of Etriché approved in 2014 aims to refocus the development of urbanization in the center-town by filling the hollow teeth (Figure 7).

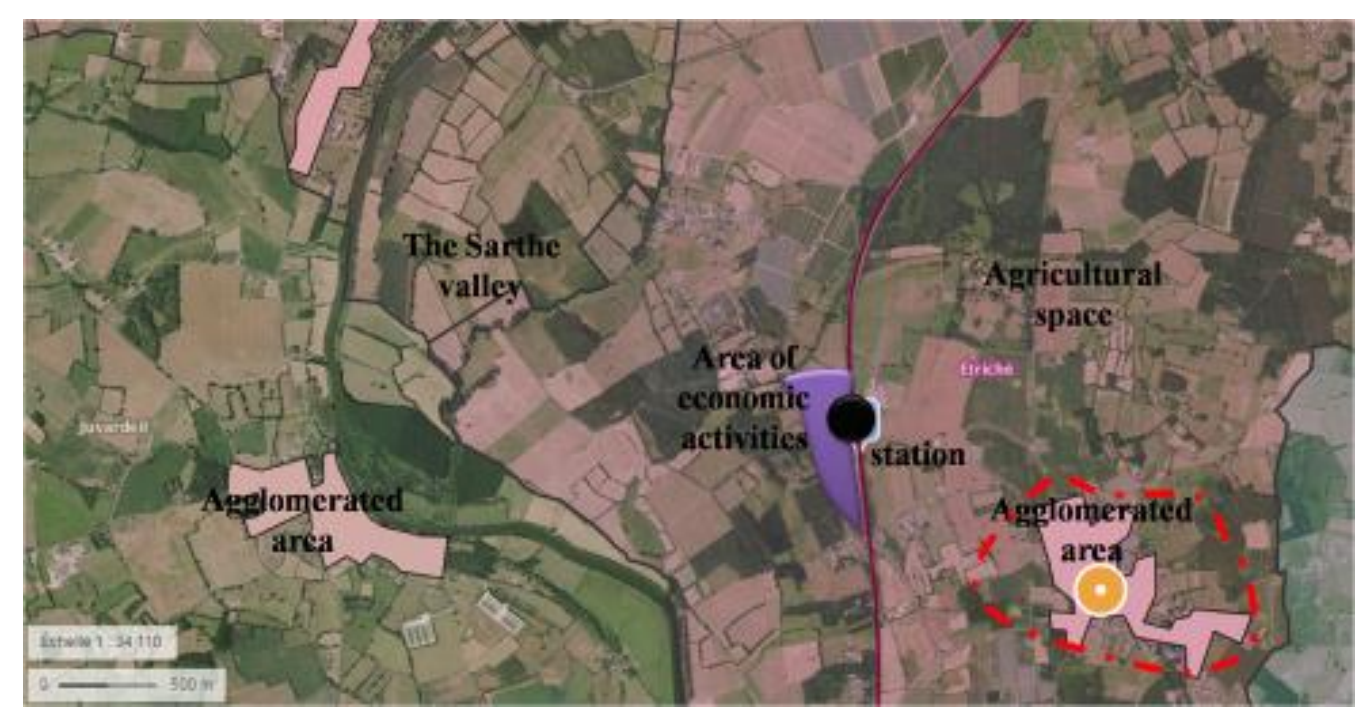

Figure 7. No Densification around the Station of Etriché

Source: http://www.geoportail.gouv.fr.

Concerning La Possonnière, the PLU plans at the commune level are a rate of new constructions of about fifteen dwellings per year and an average density of 17 dwellings per hectare. In so doing, areas to be urbanized are identified within the urban envelope to accommodate different types of housing: individual, pure, grouped and collective. There are no areas near the railway station due to two constraints:

- The railway infrastructure serving the territory is simultaneously an urban break and a source of noise nuisance,

- The land south of the railway is flooded.

Parallel to this lack of potential for densification around the station, the commune wants to promote its connectivity by creating around the large village a green loop, which will be accompanied by the development of soft links within the urban fabric to encourage modes of travel alternatives to the car toward the generators of flows (particularly the railway station.) ${ }^{17}$

17. The building of this station still exists and the signage is present and visible. 


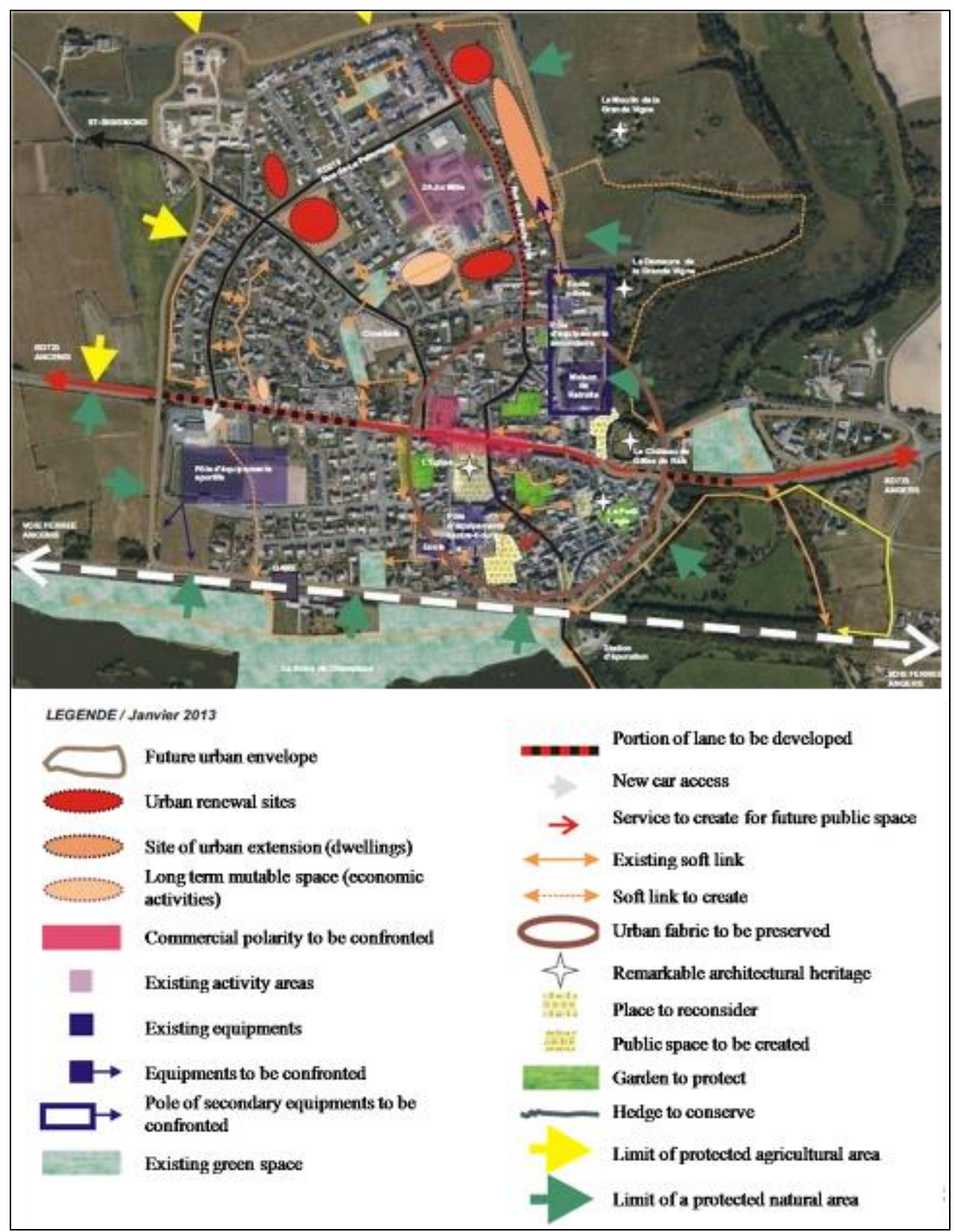

Figure 8. Development of the Large Village of Champtocé-sur-Loire Source: PLU of Champtocé-sur-Loire.

The example of Champtocé-sur-Loire is similar to the previous one. There is no potential for densification around the station for the same reasons mentioned above. The urbanization of the large village was initially limited between the regional road 723 and the railway, then from the 1980s, the urban extensions crossed the limit of the regional road towards the North. The railway marks the southern limit of the urbanization of the large village where a flood zone is located. In addition to this urban cut-off effect, the two transport infrastructures (road and rail) create another cut-off effect on pedestrian continuities between the northern districts and the center of the village. In 
order to mitigate this, the will of the elected representatives through the PLU consists in creating and securing a north-south soft link between the regional road and the railway station (Figure 8.) In terms of urbanization and urban renewal, the commune's strategy is to diversify the supply of housing (intermediate, individual, grouped, etc.) to support a population of 2,000 inhabitants in 2023 (Based on a population growth of $1 \%$ per year.) This slower rate of population growth aims to adapt the supply of equipments and to support the activity of shops and services in the commune.

Possibility to Coordinate Urban Planning and Transportation in Tiercé

The station of Tiercé enjoys a strategic location in the urban area of the large village (UA zone). This area is characterized by a dense and structured organization, marked by the quality and the architectural sensibility of the old buildings. For this example, there is a possibility of densification around this station with the opening of some zones to urbanization (AU) in continuity of the dense urban fabric (Figure 9.) The possibility to coordinate urban planning and rail transport aims to strengthen the quality and the organization of the large village while preserving biodiversity.

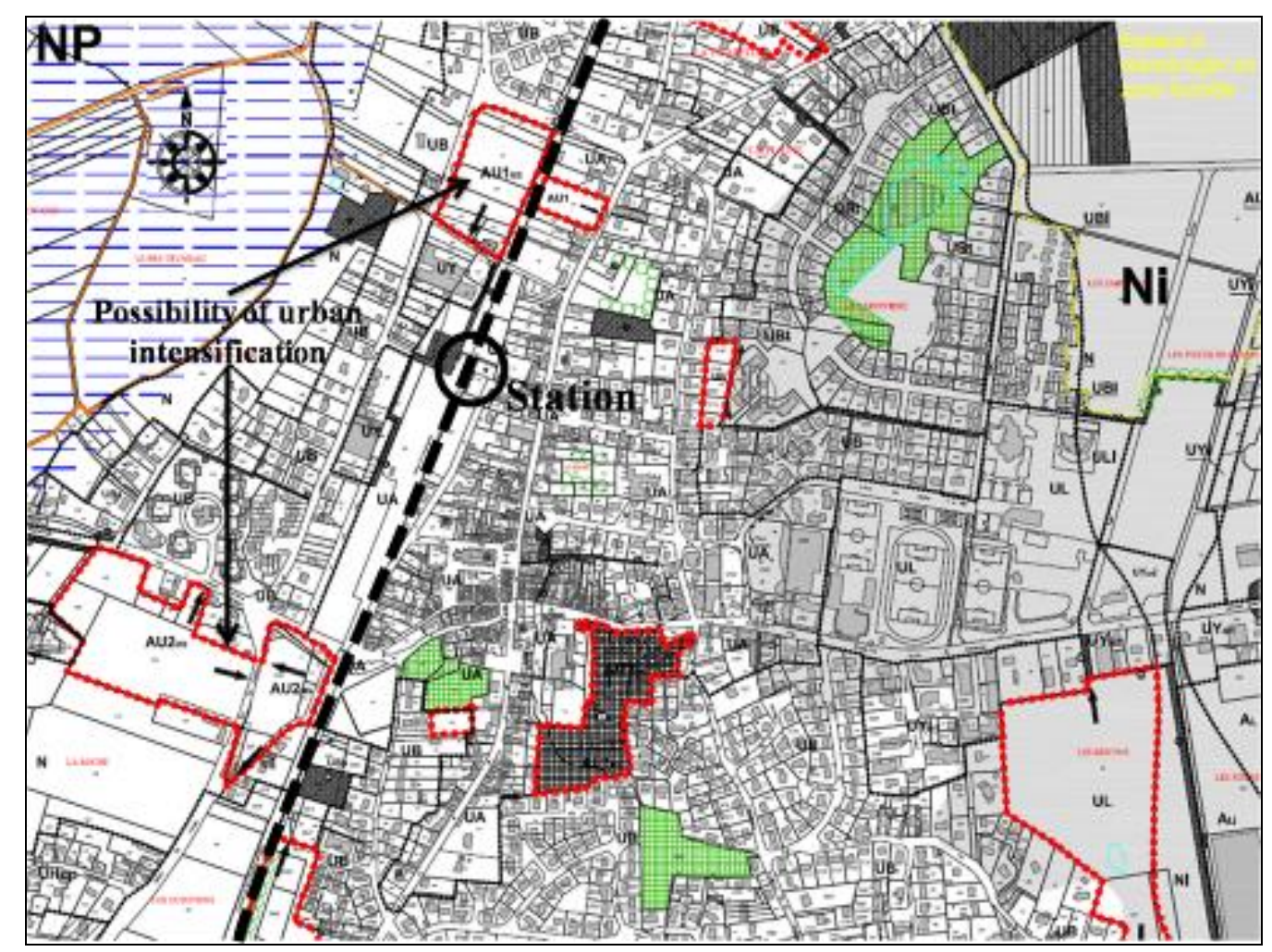

Figure 9. Zones AU in front of the Station of Tiercé

Source: PLU of Tiercé. 
A Development Charter for Articulating Displacements and Urban Development at the Intercommunal Scale

The Angers-Saumur railway axis represents a strong potential for the development of infrastructures and urban planning at the peri-urban level, but it faces limits due to natural constraints. To see how the local authorities valorize this axis around the railway stations, we read the charter of development and urbanism of the local council community of the valley Loire Authion. The document is provisional, but it is a real tool for decision-making at the intercommunal level, even if it does not have a regulatory scope. It also introduces the topic of transportation and contains interesting information in terms of articulation between urban development and displacements. In general, the intercommunal territory is served by three railway stations: La Bohalle, Saint Mathurin and La Ménitré, which have advantages and disadvantages in terms of accessibility (Table 1.)

The territory is also served by three main roads: the A11 motorway in the north, the D347 in the center and the D952 in the south, and has a dense internal service (to be improved.) The D347 is the economic axis of the local council community where the majority of economic activities zones were developed. This axis supports an important traffic accentuated by the demographic development of the East of Angers.

Table 1. Advantages and Disadvantages of Stations

\begin{tabular}{|c|l|l|}
\hline \multicolumn{1}{|c|}{ Station } & \multicolumn{1}{|c|}{ Advantages } & \multicolumn{1}{c|}{ Disadvantages } \\
\hline \multirow{5}{*}{ Saint Mathurin } & $\begin{array}{l}\text {-Central position of the } \\
\text { station } \\
\text {-Easy access by bike, by car } \\
\text { and on foot } \\
\text {-enjoyable surroundings } \\
\text {-Building in a good condition } \\
\text { (currently music school) }\end{array}$ & $\begin{array}{l}\text { - No buses but coaches linking } \\
\text { with Angers and other } \\
\text { communes }\end{array}$ \\
\hline \multirow{5}{*}{ La Ménitré } & $\begin{array}{l}\text {-Easy access and high tourist } \\
\text { potential } \\
\text {-Enjoyable surroundings }\end{array}$ & $\begin{array}{l}\text {-No buses but coaches linking } \\
\text { with Angers and other } \\
\text { communes } \\
\text {-No crossing area }\end{array}$ \\
\hline La Bohalle & \multicolumn{1}{|c|}{$/$} & $\begin{array}{l}\text {-No bike paths } \\
\text {-No buses but coaches linking } \\
\text { with Angers and other } \\
\text { communes } \\
\text {-Station accessible only by car }\end{array}$ \\
\hline
\end{tabular}

Source: Guillant, 2002. L'optimisation du transport de voyageurs par voie ferrée sur l'agglomération angevine dans le cadre de son PDU. Master's Thesis. Université d'Angers. 


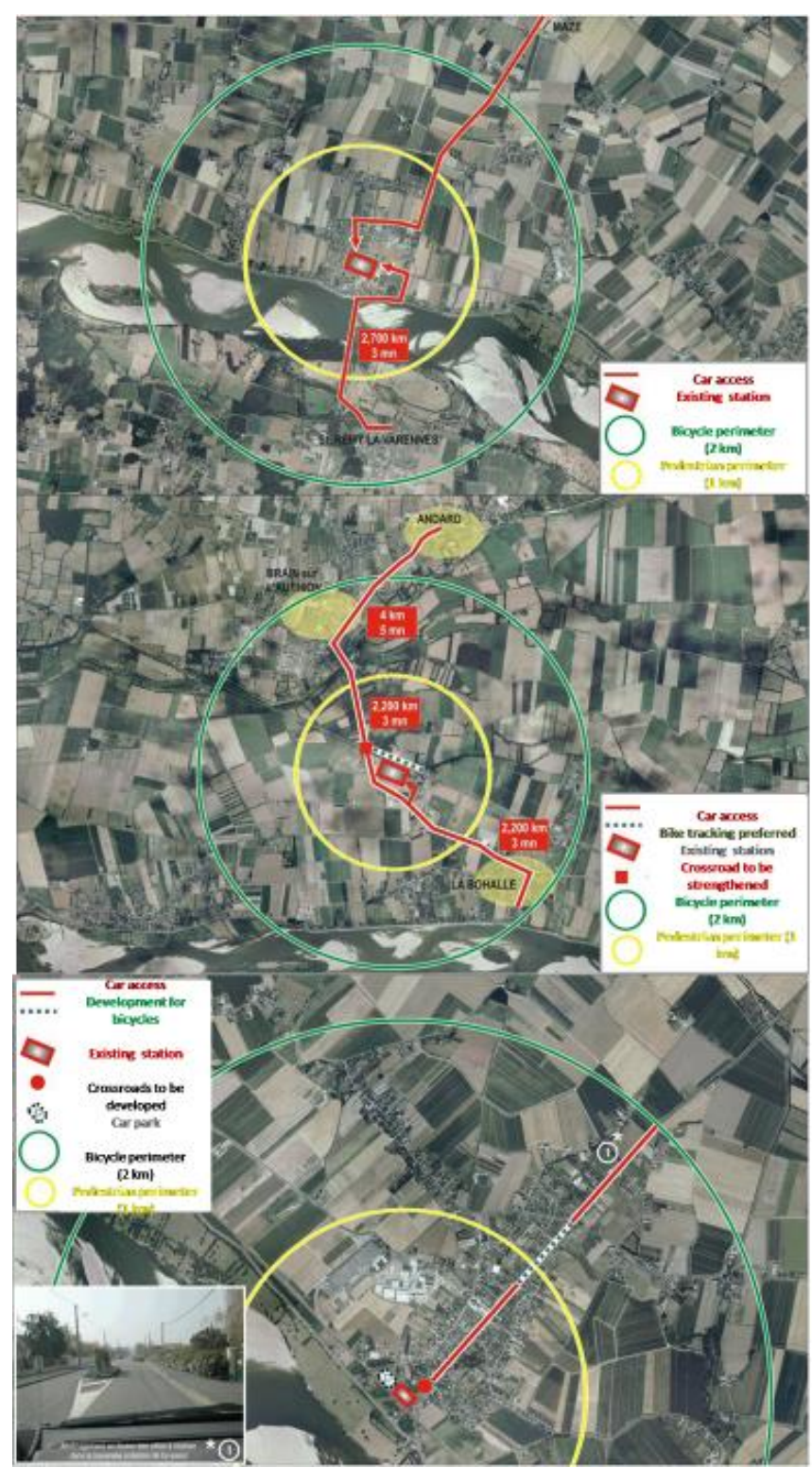

Figure 10. Improve Accessibility to the Three Stations

Source: Charter of Development and Urbanism of the Local Council Community of the Valley Loire Authion, December 2013.

The congestion on the D347 at peak times leads to longer journey times. This requires the development of alternative modes in the context of sustainable development such as carpooling, express bus lines, etc. Falling people on railway stations to thwart the use of the car is another solution envisaged. To do this, several developments are planned (Figure 10) which will help to ensure attractiveness and facilitate accessibility to the three railway stations:

- Short-term development of a bicycle route (7 minutes) between Brainsur-l'Authion and the station of La Bohalle.

- Proposal for new equipment on the station of La Bohalle, financed by the local council community and the communes of La Bohalle, 
Andard and Brain: drawdown transportation on demand towards the station, creation of a cycling route between the three communes, setting up a service of tickets sale of transport in the businesses of Brain and Andard.

- Improvement of cycle routes for the inhabitants of Saint Mathurin and Saint Rémy La Varenne.

- Search for downtown avoidance routes to reach the Saint Mathurin station by car (from the South and the North).

- Improvement of the car park at Saint Mathurin station and installation of the crossing of the tracks.

- Improvement of the access to La Ménitré station by creating twowheeled routes and setting up the Loire by bike on the right bank.

- Reinvestment of the local station, creation of a car-pooling car park and a multimodal platform at La Ménitré station.

- Improvement of the railway service by adding a train at 8am from Angers to La Ménitré.

In spite of these proposals, the coordination between urban planning and rail transport remains difficult to implement since the communes that build the most are located in the North of the local council community while the stations are located in the South.

\section{Urban Projects around the Stations of Nantes}

As of August $1^{\text {st }}$ 2014, all communes served by railway stations are covered by approved PLU. The communes forming part of Nantes Métropole will soon be covered by an intercommunal PLU which is at present prescribed.

The reading of the various documents reveals a rather positive assessment of the relationship between urban planning and rail transport. The case of Nantes is a site offering practices and reflections on railway stations at the urban and interurban scale. We mainly have communes which tend to improve the connectivity of the station, communes whose district around station is the subject of reflection in the framework of an international competition, and communes which call for reflections outside the local authority before any procedure for the operational implementation of projects. We feed our comments with examples of these different practices.

\section{Connectivity of the Station to the Rest of Communal Territory}

The commune of Mauves-sur-Loire constitutes a first example because the valorization of the station and its district constitutes the main orientations of the PLU. The station has already been upgraded, but more needs to be done to improve access and to provide parking areas to cater for the high demand of the regional express train. Connectivity will be reinforced by the development of soft paths in order to create links to the station (Figure 11.) 
The district of the station is classified zone UA which has for vocation to welcome inhabitants, central activities (services, equipments, etc.)

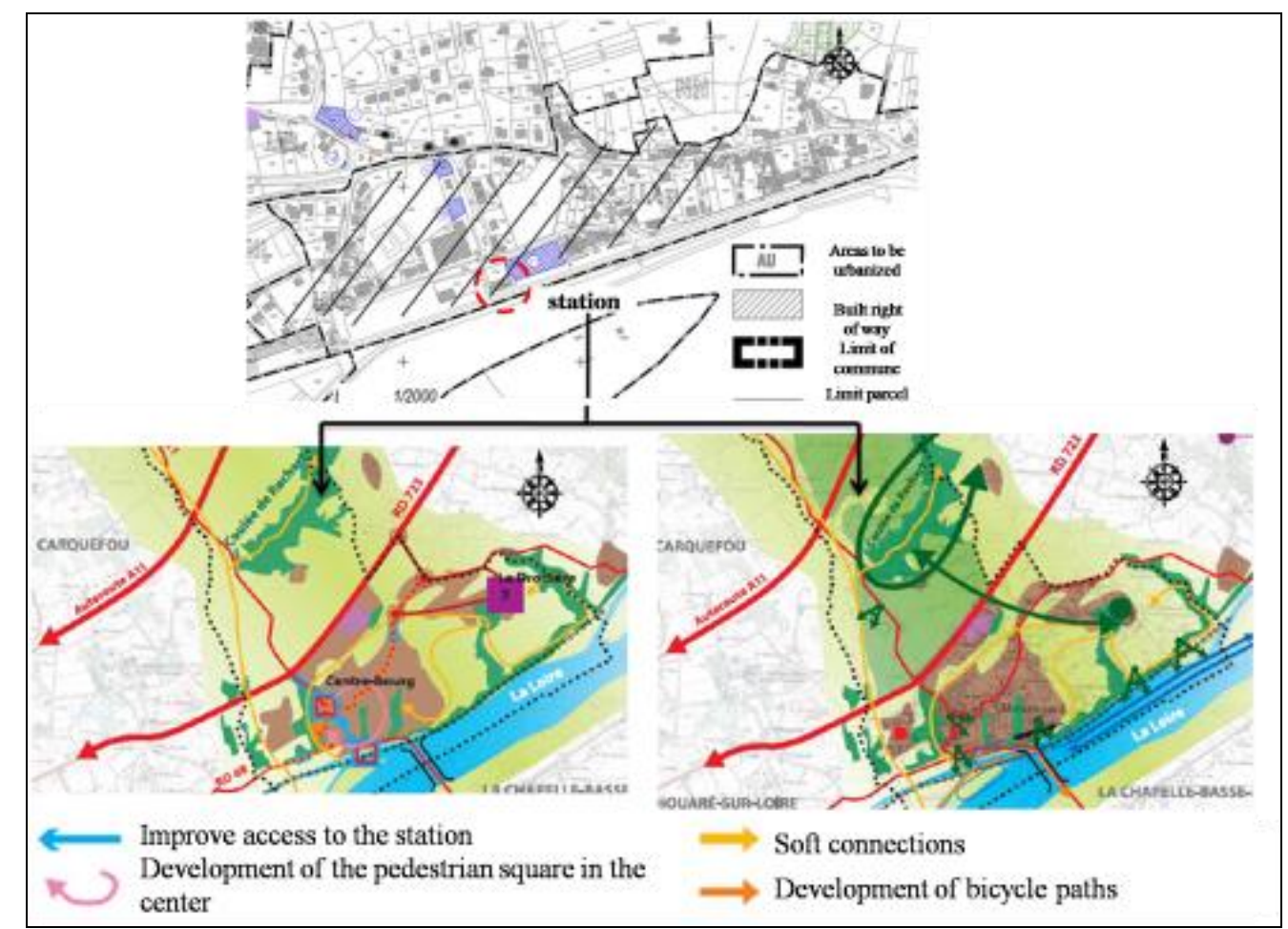

Figure 11. Strengthening the Connectivity of the Station

Source: PLU of Mauves-sur-Loire.

The commune of Le Cellier is another example favorable to the connectivity of the station to the communal and intercommunal territory. In doing so, the PLU envisages several objectives to promote mobility for all:

- Strengthen intermodality (train, bus) and individual transport in logic of intercommunal cooperation.

- Develop modes of soft travels (pedestrians, bicycles).

- Promote better sharing of public space.

- Create a shared lane allowing cycles and pedestrians to connect the station to the South. Moreover, the railway station will be conceived as a multimodal platform (parking-relay, car-pooling platform, trainbus-car-bike,) that benefits all inhabitants at the communal and intercommunal level (Figure 12.) Regarding the densification, it is no potential around the station of Le Cellier because of the urban morphology of the large village which is characterized by the presence of physical constraints such as the motorway, the railway and the regional road. Urban development is planned towards the North in continuity with the existing to avoid on the one hand the urban sprawl of natural or agricultural areas and to preserve on the other hand the rural and urban identity of the commune. 


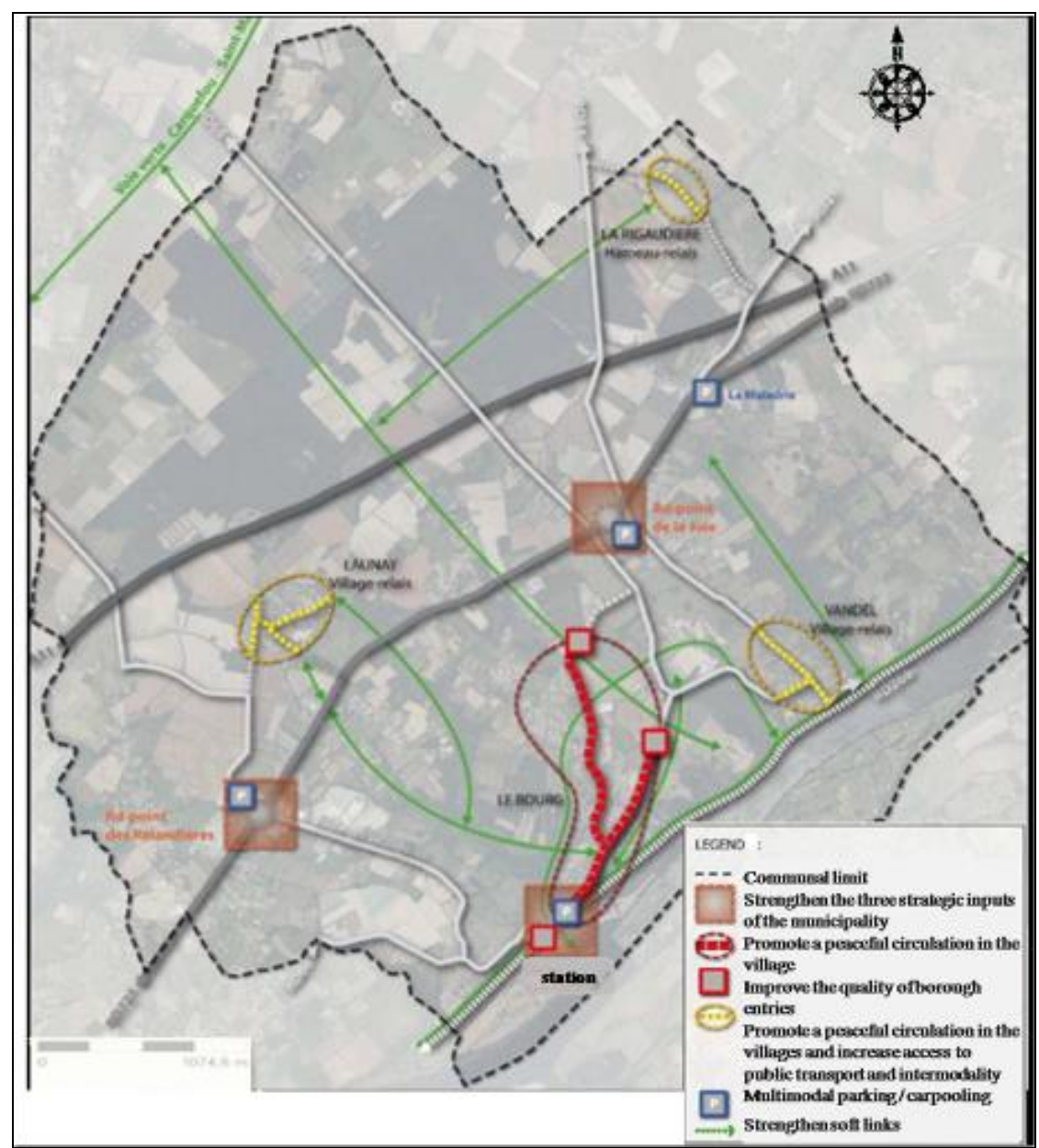

Figure 12. Connectivity from Station to Territory

Source: PLU of Le Cellier.

\section{Possibility of Densification around the Station}

The station of Thouaré-sur-Loire is the object of several adjustments with the aim of making it a true multimodal pole within the city. These improvements relate to the qualification of public spaces as well as lay-bys and accessibility. In order to manage the impacts of demographic growth and cater for new housing demands, the commune plans to build about 100 dwellings per year. The sector of the station can be densified since it is classified zone 1AUa destined to be open for urbanization. This future cluster will be linked to the future districts to be planned by the PLU through the integration of soft links and the development of the mesh structure (Figure 13.) 


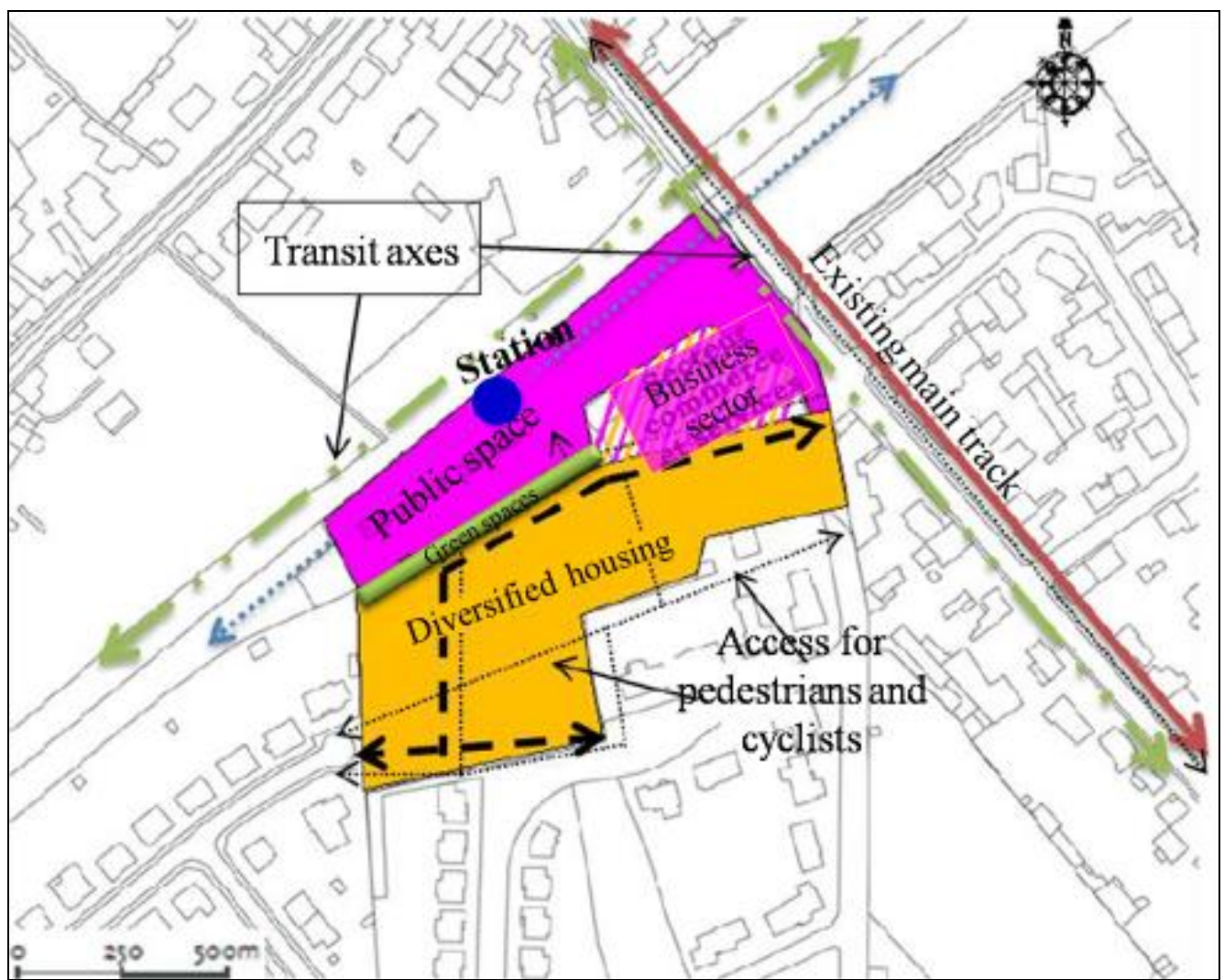

Figure 13. Develpment of the Station Sector

Source: PLU of Thouaré-sur-Loire.

For Cordemais, the potential for densification is also possible around the station. This densification makes it possible to reinsert the station into the urban fabric projected and therefore facilitate its accessibility. The sector of the station (Croix Morzel) is classified in $1 \mathrm{UA}_{\mathrm{Z}}$ zone (15.47 hectare) which is destined for a concerted urbanization. The latter will be accompanied by the provision of parking for cars (Figure 14.) The station has certain weaknesses (situation 2013) which require improvements and an evaluation of difficulties and land possibilities by French National Society of Railway (SNCF): insufficient parking space, parking of vehicles along the railway track and on the car-pooling area. At the same time, the sector of La Croix Morzel will benefit from the preservation and comfort of shops. The PLU concentrates on densifying the large village and the station sector through mastered operations and linking them through soft links. 


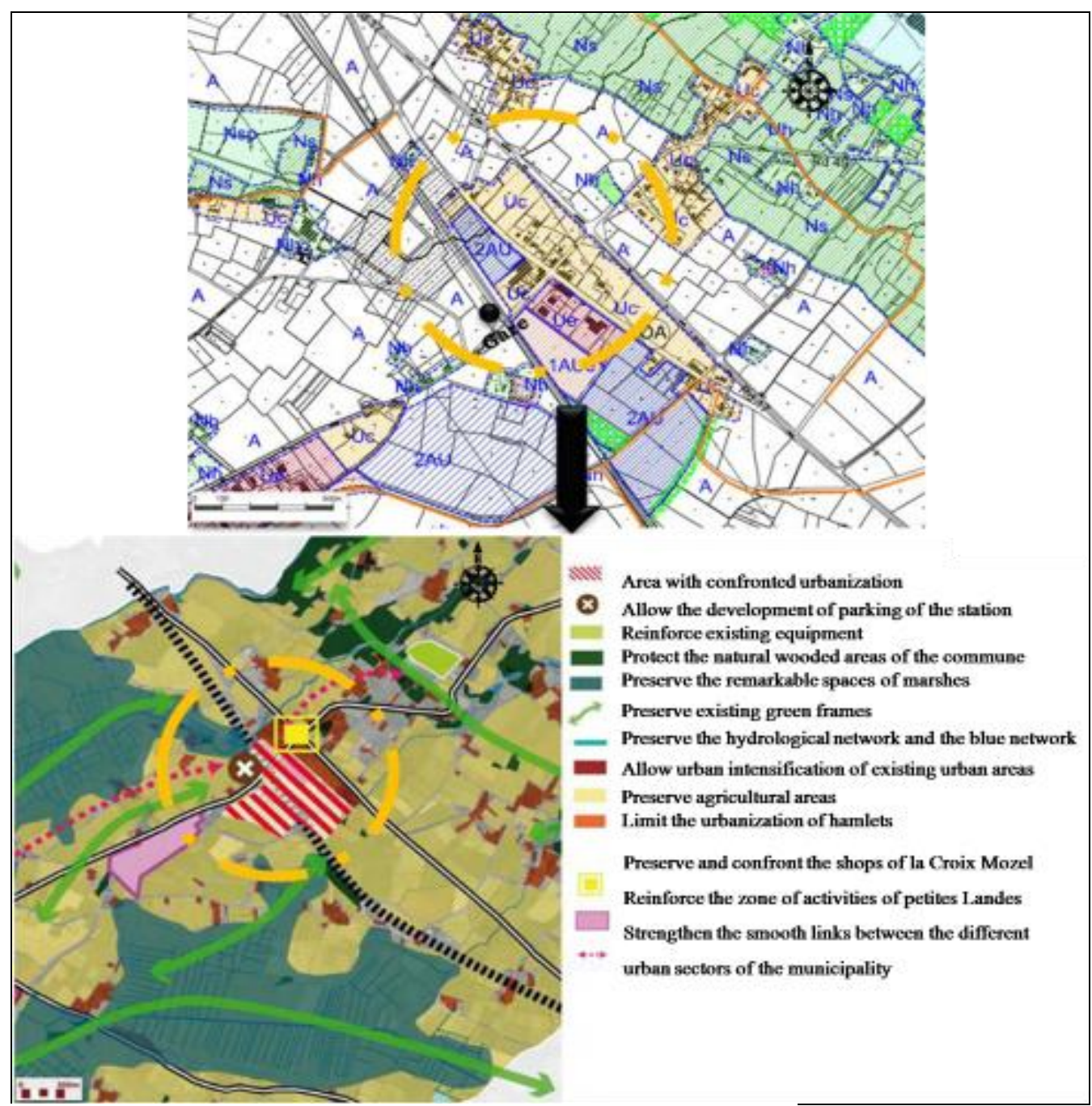

Figure 14. Densification around the Station of Cordemais

Source: PLU of Cordemais.

Densification is also possible around the station of Saint-Etienne-deMontluc thanks to the presence of several zones AU. These zones are mostly along the railway:

- The mixed-use zone AUb intended to receive residential constructions of average density.

- The mixed-use zone AUg intended to receive collective housing and high density services (sector of the station).

- The AUec zone with an economic vocation intended to receive artisanal and commercial buildings. These three zones devoted to the development of the commune show that there is a desire to ensure the compactness of the large village and the complementarity of functions and services. Incidentally, there are planning and programming guidelines (OAP) for these three sectors in which we insist on the principle of connectivity of each sector and the principle of acoustic insulation by creating hedges (Figure 15.) 


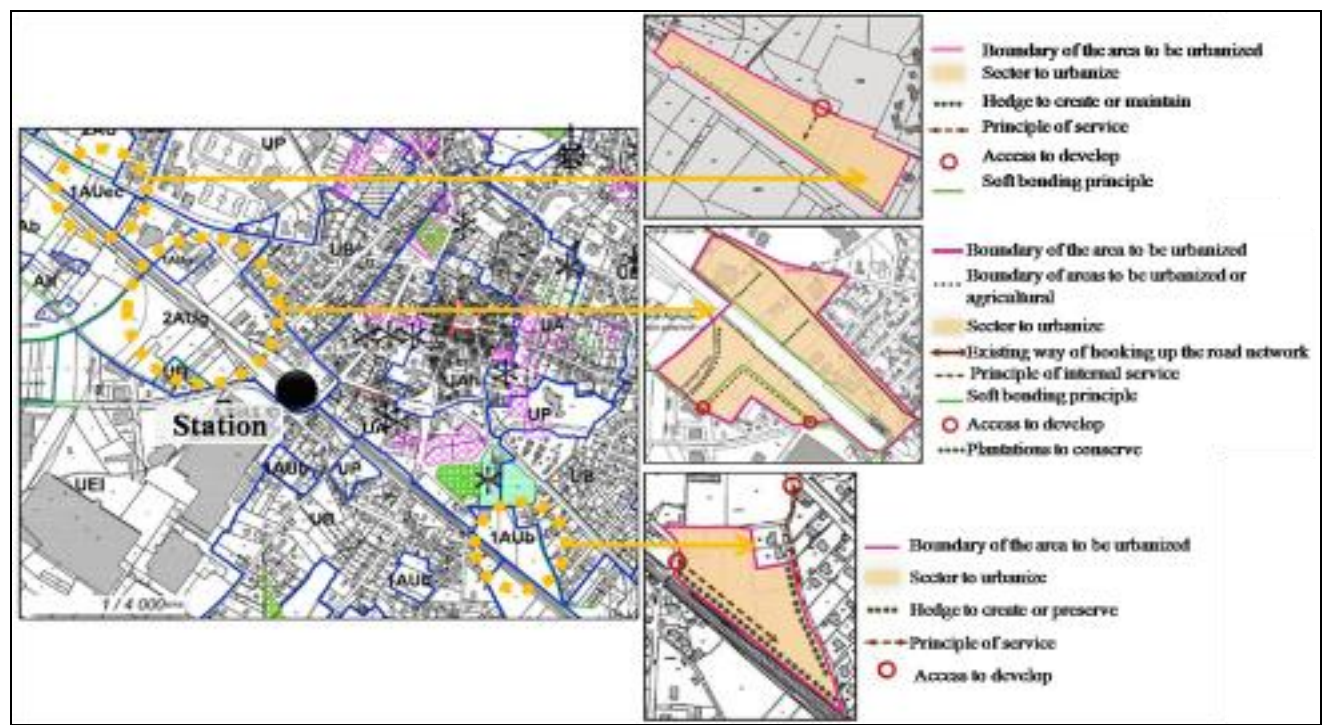

Figure 15. Compactness of the Large Village of Saint-Etienne-de-Montluc Source: PLU of Saint-Etienne-de-Montluc.

In another order of ideas, the lands abandoned around the station were bought by the commune from the SNCF in order to densify and extend the parking of automobile for a greater use of train. The station of Saint-Etiennede-Montluc was the subject of a study carried out by the Center of technical studies of equipment (CETE de l'Ouest) in July 2005, at the end of which several orientations and proposals were presented to improve the access to the station and enhance the use of train (Figure 16.)

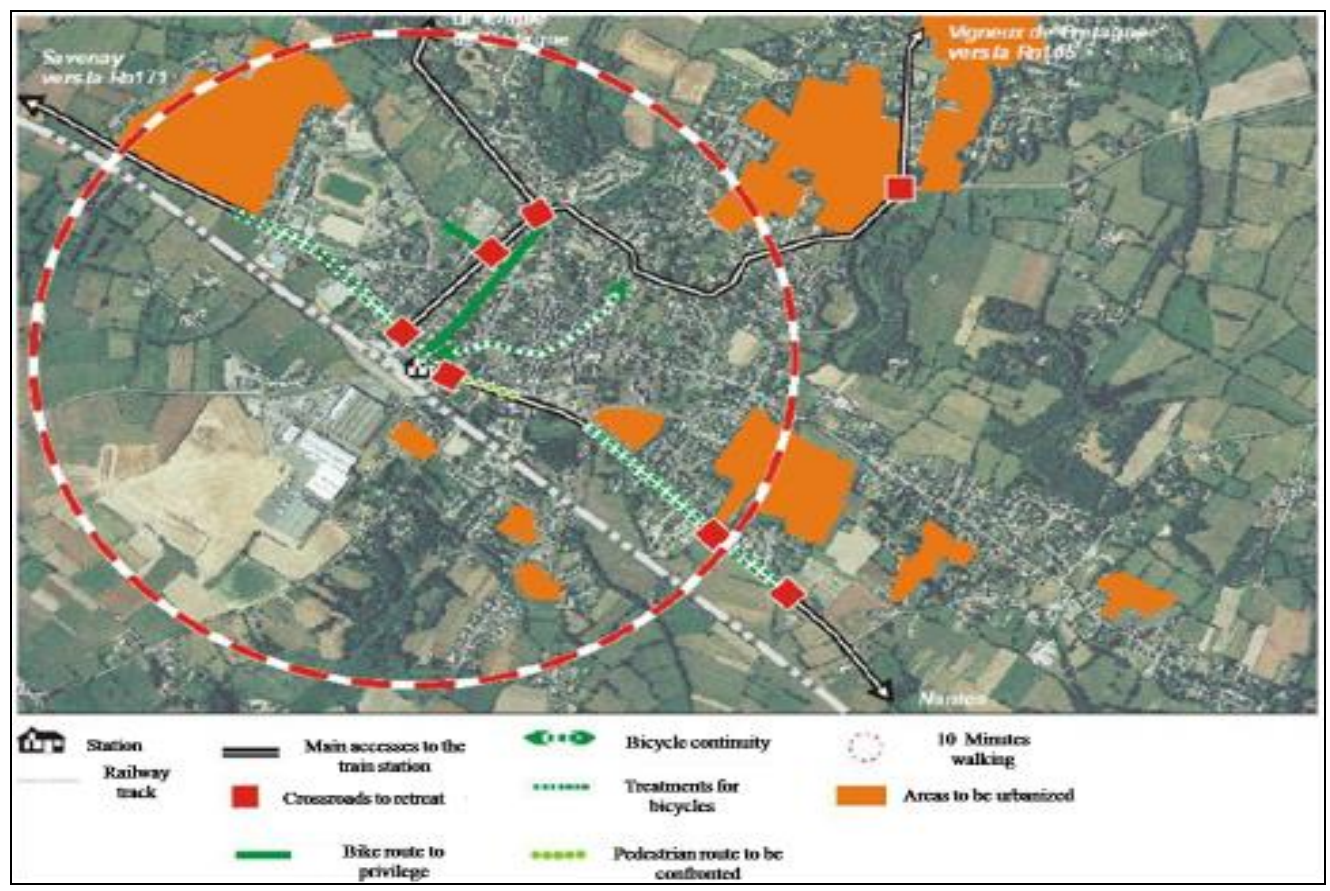

Figure 16. Orientations of the CETE de l'Ouest for the Station of Saint-Etiennede-Montluc

Source: CETE de l'Ouest, Saint-Etienne-de-Montluc, July 2005. 
Urban Projects around Stations, an Opportunity to Coordinate Urban Planning and Rail Transport

The two examples of Savenay and Sainte Pazanne illustrate the idea of an urban project structured around the peri-urban station and reflected in the framework of a sustainable urban development.

The commune of Sainte Pazanne is attractive and in the process of extension, so, it is important to think about its urban development in a sustainable way to counter the temptation to urban sprawl. To this end, potentialities for densification around the station (housing and economic activities) exist and opportunities of development in the wastelands of the commune are to be seized (Figure 17.) In this context, the regional Direction for Territories and the Sea of Loire-Atlantique (DDTM) conducted a reflection on the sustainable development of Sainte Pazanne station's neighborhood and proposed it to the local authority before any operational process on the site. In doing so, the work was entrusted to a specific workshop in order to make exploratory proposals for the future neighborhood. This workshop is made up of the services of the DDTM, a group of students of Master's degree (University of Nantes,) teachers referring to the University of Nantes, council of architecture, urbanism and environment (CAUE), urban planning agency of Nantes (AURAN) and the architect of the DDTM. The work carried out is of high quality by articulating four important pillars (Table 2.) The students produced several documents following the diagnosis and the proposals phase. ${ }^{18}$

Table 2. Proposition of Students

\begin{tabular}{|c|l|}
\hline Main pillars & \multicolumn{1}{c|}{ Workshop proposals } \\
\hline Compactness & $\begin{array}{l}\text { Restructuring of the existing urban fabric } \\
\text { Variety of dwellings and social mix }\end{array}$ \\
\hline Complementarity & $\begin{array}{l}\text { Promotion of a balanced commercial offer in } \\
\text { complementarity to the existing offer } \\
\text { Creation of a commercial centrality at the station }\end{array}$ \\
\hline Connectivity & $\begin{array}{l}\text { Crossing the railway line } \\
\text { Creation of an exchange multimodal station } \\
\text { Promotion of an efficient offer of public transport for } \\
\text { the service of commune and territory } \\
\text { Development of soft links mesh }\end{array}$ \\
\hline \multirow{3}{*}{$\begin{array}{c}\text { Symbiosis between man } \\
\text { and environment }\end{array}$} & $\begin{array}{l}\text { Valorization of rural landscapes and green spaces } \\
\text { Conciliation between sustainable development and } \\
\text { demand of individual gardens } \\
\text { Proposition of quality collective spaces }\end{array}$ \\
\hline
\end{tabular}

Source: http://bit.ly/2DfMWQv.

18. These documents are available on the website of the state services in Loire-Atlantique: http://bit.ly/2mfINnd. 


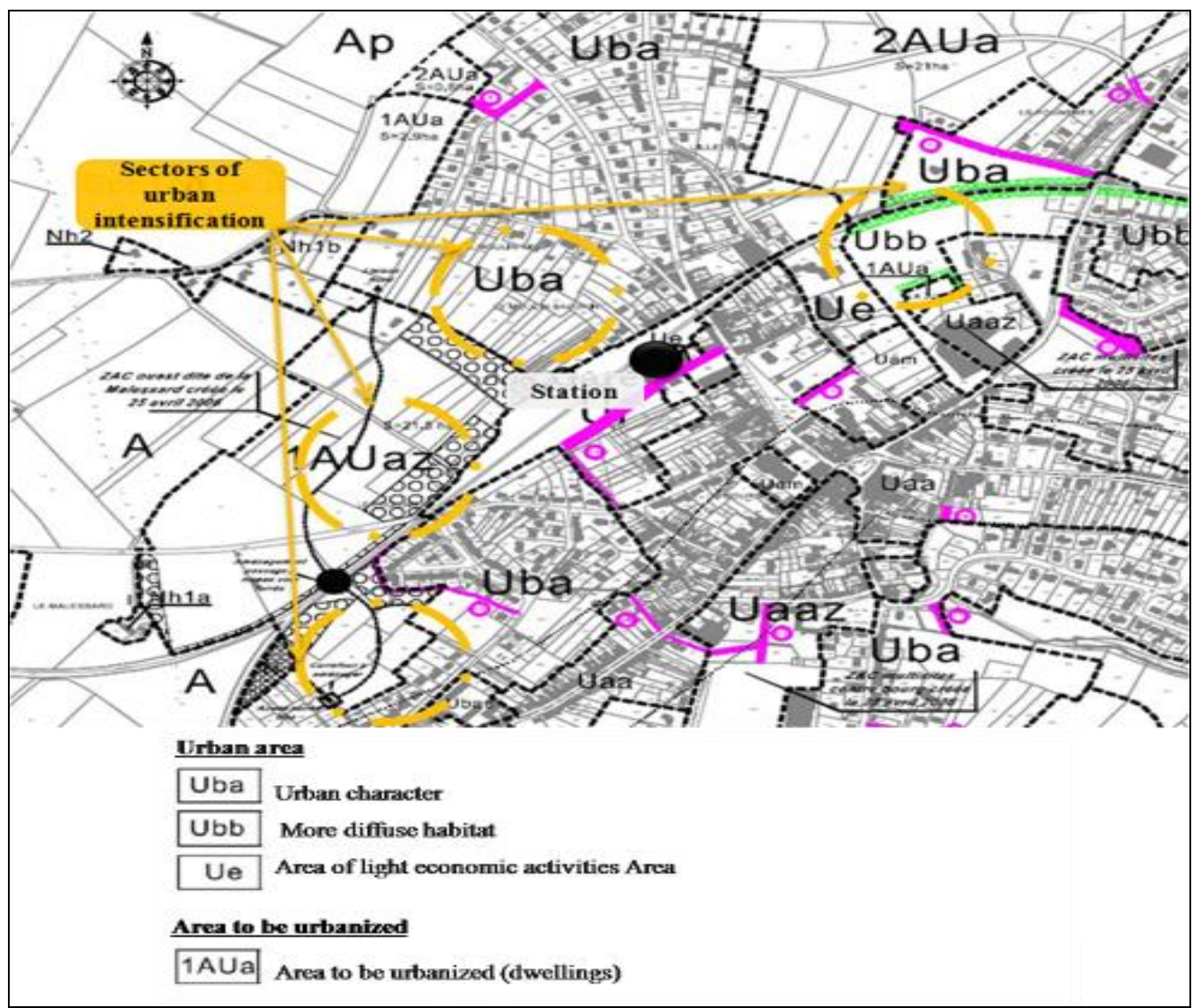

Figure 17. Sectors to be densified around the Station of Sainte Pazanne Source: PLU of Sainte Pazanne.

Concerning the example of Savenay, the commune has a railway station located between Nantes and Saint Nazaire. In recent years, it is responsible for $14 \%$ of commuting destined for Nantes and $21 \%$ for Saint Nazaire. In 2008 , the transformation of this station into a multimodal exchanges pole was approved, and this project, an asset in terms of mobility, is underway, with the extension of the underground, the accessibility for persons with reduced mobility and the improvement of the building. The free parking belonging to SNCF réseau (made available through conventions) constitutes one of the weak points of this station. Indeed, users come to the station by car, which generates the saturation of the parking and therefore necessitates the creation of a new parking area.

The objective of PLU is to ensure the coherence urban planning/ transportation by coordinating social mix, infrastructures and densification. Concerning the railway station, its sector (Figures 18 and 19) was selected as a study site during the European program "Europan and the ecoCities." Several multidisciplinary teams (architects, urban planners and landscapers) made proposals, but only three were selected by the jury. This selection is followed by a reopening of competition in order to elect the project management team whose task is the operational implementation of the project. In this context 
and following an urban consultation in 2013, the team "mesures ligériennes" was chosen for the development of the future district of the station.

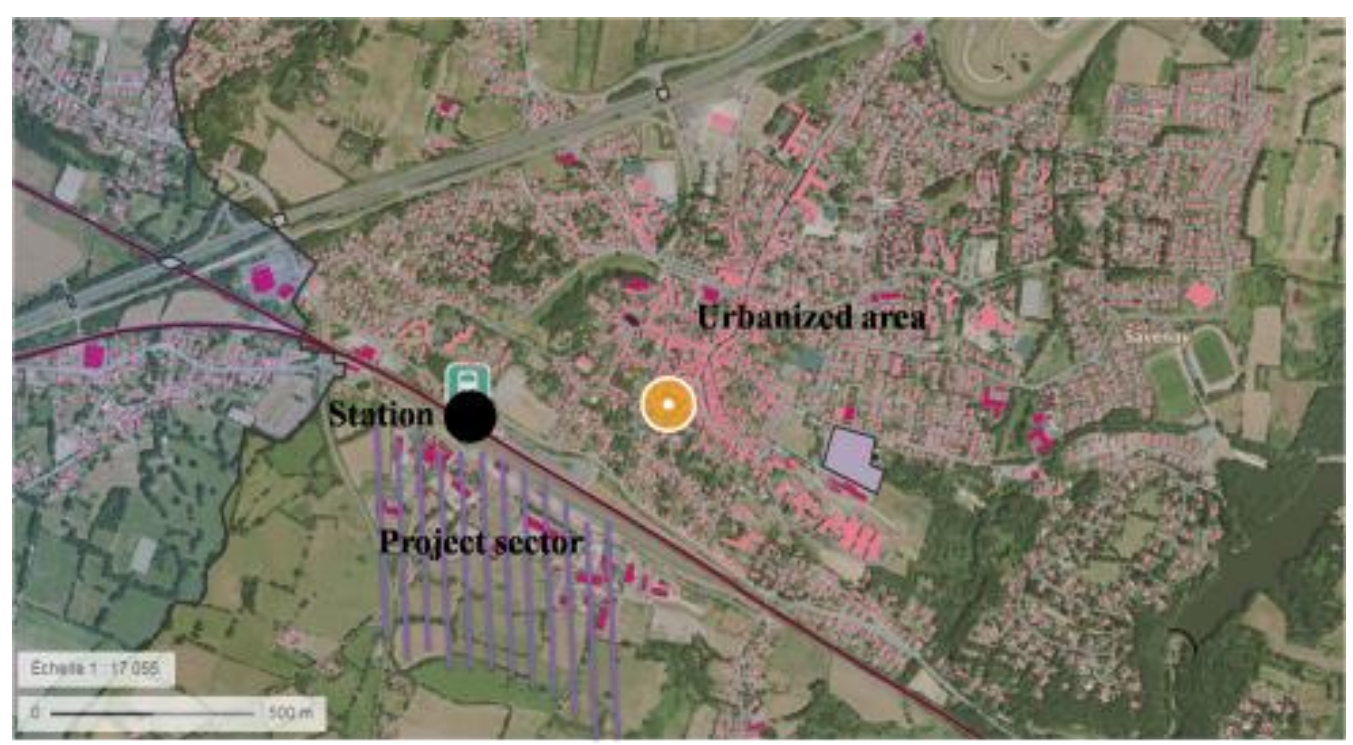

Figure 18. A Multimodal Exchanges Pole in the Service of an Urban Project Source: http://www.geoportail.gouv.fr.

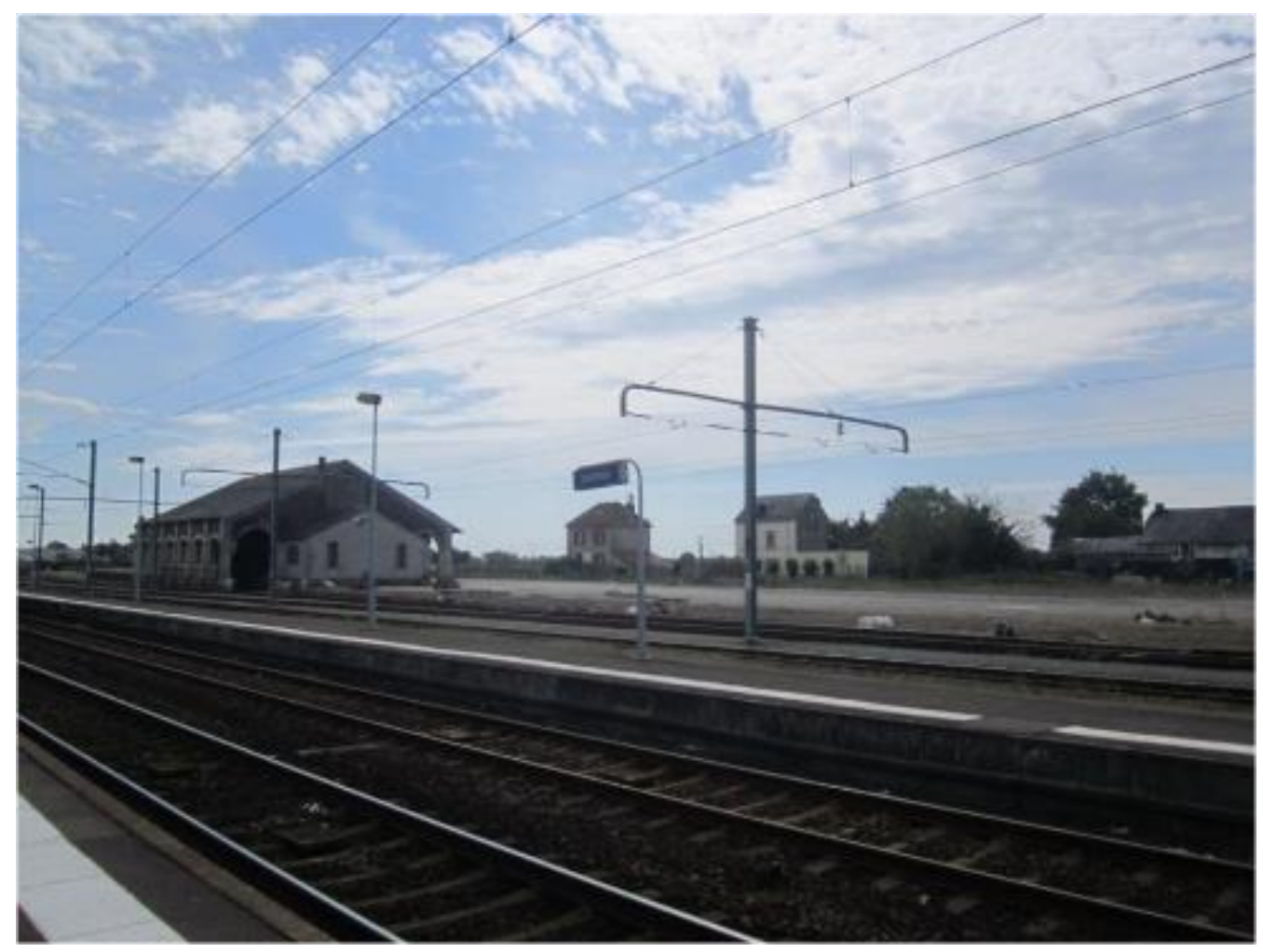

Figure 19. Location of the Future Urban Project

Source: Author, September 2014.

In order to outline the final character of the future neighborhood in an ambitious and innovative way, the team "mesures ligériennes" follows a co- 
production process, which involves debating the project with the local actors, inhabitants and users. The team elaborates different diagnoses (uses, nature and mobility) in order to discern the disadvantages and the assets of the territory. The wasteland will be restructured with 1,000 dwellings and 2500 inhabitants (mixed urbanization: housing and economic activities.) At the same time, public transport shuttles linking the railway station to the main generators in the catchment area of the station will be considered in the future, and it is envisaged to equip the station with services such as shops in order to avoid displacements related to the main movement. ${ }^{19}$

\section{Conclusions}

The city, which is structured by the railway, has become an essential part of the political and technical discourse around the sustainable city ${ }^{20}$. It is not easily achievable because we cannot opt for the same projects and with the same orientations along a railway axis. The communes served by the railway are characterized by multiple intercommunal affiliations and at each different scale; the actors apprehend the territory differently according to the observation, the foresight and the decision.

Moreover, this morphological and regulatory study shows that the periurban stations do not offer the same development logics and consequently opportunities or not to articulate urban planning and transportation. The analysis of the different policies carried out to reconcile urbanization with the stations shows a plurality of strategic profiles of communes: communes without strategies and without projects, communes with a strategy for employment, communes with a strategy for housing, communes with a project articulating urban planning and displacements.

As a corollary, not all stations districts are necessarily future sites and it would be advisable to focus the interest on railway stations which have a high potential for territorial development and displacement. However, densification around railway stations remains problematic and it constitutes a highly voluntarist model ${ }^{21}$ conditioned by planning of sectors. ${ }^{22}$

19. www.europan-europe.com/e11/uploads/sites/savenay-FR_fr.pdf.

20. J. Maulat, "La desserte ferroviaire des territoires périurbains. Construire la ville autour des gares (Bruxelles/Milan/Paris/Washington,)" (ed.) Anne Grillet-Aubert, Bénédicte Grosjean, Géry Leloutre, Paola Pucci, Colas Bazaud and Karen Bowie, Flux 2016/4, no.106 (2016): 101-104.

21. T. Littman, Affordable-Accessible Housing in A Dynamic City. Why and How To Increase Affordable Housing Development. Accessible Locations (Victoria Transport Policy Institute, 2010).

22. M.-C. Fourny, G. Feyt, T. Leysens, S. Duvillard, K. Koop and M. Talandier, "Quelle gouvernance territoriale pour une urbanisation orientée par le rail dans les aires métropolitaines? Les leçons d'une expérimentation régionale," in Colloque ASRDLF 2013 "Cultures, patrimoines et savoirs." Université Catholique de Louvain, 2003. 


\section{Acknowledgments}

My thanks go to the town halls of peri-urban communes (town planning service) which provided me the various urban planning documents and to persons who explained to me some communal and intercommunal projects: Cécile Coyez (service of economic development, local council community of the Vallée-Loire-Authion), Sophie Bosvy (service of urban planning of Savenay), Matthieu Georget (mixed union of Pays-du-Mans) and Emmanuel Bled (transportation service, local council community of Loire-et-Sillon).

\section{Bibliography}

Ascher, F. Dynamiques métropolitaines et enjeux sociopolitiques [Metropolitan dynamics and socio-political issues.] 1995. http://bit.ly/2D0UMAg. . L'âge des métapoles, préface d'Alain Bourdin. La Tour d'Aigues [The age of metapoles, preface by Alain Bourdin. The Tower of Aigues.] Editions de l'Aube, 2009.

Aura. La ville, toujours plus loin? (Portraits du périurbain angevin) [The city, ever further? (Portraits of the peri-urban Angevin.)] AURA editeur, 2012.

Baron, N. and N. Roseau. "Les gares au miroir de l'urbain" [Train stations in the mirror of the urban.] Flux 2016/1, no.103-104 (2016): 1-8.

Bonnet, G., A. Canet, L. Houles and B. Thomé. La régionalisation des transports ferroviaires. Enseignement de l'expérimentation et perspectives [Regionalization of rail transport. Teaching experimentation and perspectives.] Lyon: CERTU, 2001.

Brès, A. "Train stations in areas of low density and scattered urbanisation: towards a specific form of rail oriented development." Town Planning Review 85, Issue 2 (2014): 261-272. DOI:10.3828/tpr.2014.16.

Certu. Effet de serre, organisation urbaine, politiques de déplacements [Greenhouse effect, urban organization, travel policies.] Journée d'étude, Octobre 2003.

Da Cunha, A., P. Knoepfel, J.-P. Leresche and S. Nahrath. Enjeux du développement urbain durable: transformations urbaines, gestion des ressources et gouvernance [Challenges of sustainable urban development: urban transformations, resource management and governance.] PPUR presses polytechniques, 2005.

Fourny, M.-C., G. Feyt, T. Leysens, S. Duvillard, K. Koop and M. Talandier. "Quelle gouvernance territoriale pour une urbanisation orientée par le rail dans les aires métropolitaines? Les leçons d'une expérimentation régionale" [What territorial governance for rail-oriented urbanization in metropolitan areas? Lessons from a regional experiment.] In Colloque ASRDLF 2013 "Cultures, patrimoines et savoirs." Université Catholique de Louvain, 2003.

Grebert, J., F. Toupin and J. M. Beauvais. Les petites gares du périurbain en région tourangelle: continuité territoriale et rupture de charge [Small suburban stations in the Touraine region: territorial continuity and breakage.] Atelier d'urbanisme de Tours, Paris: PREDIT, 1999.

Guillant, S. L'optimisation $d u$ transport de voyageurs par voie ferrée sur l'agglomération angevine dans le cadre de son PDU [Optimization of passenger transport by rail on the Angevin agglomeration as part of its PDU.] Master's Thesis. Université d'Angers, 2002. 
Homocianu, M. Modélisation de l'interaction transport-urbanisme-Choix résidentiels des ménages dans l'aire urbaine de Lyon [Modeling the Transport-Urbanism Interaction-Household Residential Choices in the Urban Area of Lyon.] Doctoral thesis. Université Lyon 2, 2009.

Levy, A. "La renaissance des gares" [The rebirth of the stations.] Médium 2008/2, no.15 (2008): 39-47. DOI 10.3917/mediu.015.0039.

Leysens, T. Reconfiguration des réseaux de transport et renouveau urbain: l'enjeu d'un urbanisme orienté vers le rail [Reconfiguration of transport networks and urban renewal: the challenge of rail-oriented urban planning.] Doctoral Thesis. Université Lille 1, 2011.

Littman, T. Affordable-Accessible Housing in A Dynamic City. Why and How To Increase Affordable Housing Development. Accessible Locations. Victoria Transport Policy Institute, 2010.

Maulat, J. "La desserte ferroviaire des territoires périurbains. Construire la ville autour des gares (Bruxelles/Milan/Paris/Washington)" [The rail service of periurban areas. Building the city around train stations (Brussels/Milan/Paris/ Washington.)] Edited by Anne Grillet-Aubert, Bénédicte Grosjean, Géry Leloutre, Paola Pucci, Colas Bazaud and Karen Bowie. Flux 2016/4, no.106 (2016): 101104.

Sager, F. "Institutions métropolitaines et coordination des politiques publiques: une aqqc des arrangements politico-administratifs d'articulation entre urbanisme et transports en Europe" [Metropolitan institutions and the coordination of public policies: an aqqc of politico-administrative arrangements for linking urban planning and transport in Europe.] Revue internationale de politique comparée 11, no.1 (2004): 67-84.

Stránský, V. "Des quartiers de gare favorables aux modes actifs pour une mobilité régionale énergétiquement sobre. Point de vue d'acteur" [Station areas favorable to active modes for a regional mobility energetically sober. Actor's point of view.] Flux 2017/1, no.107 (2017): 74-90.

Wackermann, G. and J. Dubois-Maury. Ville et environnement [City and environment.] Ellipses, 2005. 